\title{
Cost of Capital and Optimal Financing of Corporate Growth of Selected Manufacturing Firms Listed on the Floor of Nigerian Stock Exchange
}

\author{
Achebelema Damiebi Sam \\ Department of Banking and Finance \\ Rivers State University, Port Harcourt \\ Rivers State, Nigeria
}

\begin{abstract}
This dissertation empirically investigated the relationship between cost of capital and optimal financing of corporate growth of selected manufacturing firms listed on the floor of Nigerian stock exchange. Annual time series data were generated from the Annual Reports of the quoted firms and stock exchange fact book. Fifty manufacturing firms were selected from the population of quoted manufacturing firms. Four multiple regression models were specified and estimated with the aid of Software package for social services (SPSS). Equity financing measured as equity capital to total capital, debt financing measured as debt capital to total capital and return on investment were modeled as the function of cost of debt, cost of equity and weighted average cost of capital. The generated collinearity diagnostics result shows that the Eigen values that correspond to the highest condition index and variable constant are less than 0.5 rule of thumb. The Durbin Watson test shows absence of auto-correlation. The regression coefficient shows that cost of debt and cost of equity have negative relationship on equity financing while weighted average cost of capital have negative effect, cost of debt and weighted average cost of capital have positive relationship with debt financing while cost of equity have negative effect on the dependent variable. Cost of debt and reweighted average cost of capital have positive effect on return on Investment while cost of equity has negative effect. Model four found that cost of capital have positive relationship with financing mix of the quoted firms. From the model summary, the study conclude that cost of capital have no significant effect on equity financing and return on investment but significantly affect debt financing. It therefore recommends that Management should formulate internal policy that will enhance the realization of optimal capital structure of the firms, formulating capital structure of the firm should be well examined with the investment policy of the firms, the environmental factors should be acknowledged in formulating cost of capital to avoid risk associated with inadequate or wrong capital structure, external source of capital such as debt should be properly appraised and integrated with the investment policy and cost of equity should be integrated with the objective of maximizing shareholders' wealth through investment policies.
\end{abstract}

Keywords: Cost of Capital, Optimal Financing, of Corporate Growth, Manufacturing Firms, Nigerian Stock Exchange.

\section{Introduction}

The finance management function is a critical success factor and determines the growth, profitability and survival of firms. These functions include the dividend and the financing decision. While the dividend decision determines the proportion of earnings to be distributed to shareholders and proportion to retain, the financing decision determine the optimal combination of debt and equity to maximize shareholders wealth. The two main sources of capital are the equity and debt which both needs to be remunerated at their own lost of capital. The cost of equity can be defined as the return expected on a firm's common stock in the capital market. It represents the composition demanded by shareholders for providing capital and assuming the risk of waiting for this return. This implies that cost of equity reflects the opportunity cost of investigating in a firm's stock as opposed to potential investments with similar risks (Tushaj, 2010). Cost of debt refers to cost of external source of fund such as cost of long term debt and cost of short term borrowings.

Scholars, business executives and government decision-makers all widely acknowledge the importance of corporate financing on the growth of the firm and the economy at large. Financing decisions involve the selection of a capital structure that would minimize the cost of capital of the firm. Apart from the investment and financing decisions, managers need to decide on the optimal combination of equity and debt for financing corporate growth. However, 
the challenge is determining the optimal combination of equity and debt that reduces the cost of capital for financing corporate growth.

The relationship between capital structure and the growth of corporate firms has been a point of departure amongst scholars in the field of finance. As oppose to the relevance theory, of Gordon 1958, Miller and Modigliani known as the MM hypothesis opined that capital structure is irrelevant given some sets of assumption. This debate has deepened in modern empirical findings as many are in view of Gordon while few support the MM hypothesis. This is because the assumptions of Miller and Modigliani are seen not to exist in real world but in an abstract world (Maina \& Kondongo, 2013), (Kaunbuthu, 2011), (Abor, 2005), (Ongore, 2011). For instance CAPM has been criticize that it is based on many unrealistic simplifying assumptions (Fama \& French 2004, Young \& Saade 2011, Berkman 2013) example all the behave rationally according to their utility function that they have homogeneous expectations and that funds can be borrowed or cent at the same interest rate. This is frequently used in settings such as estimation of equity risk premiums, firm valuation and capital budgeting, and investment management practices such as portfolio allocation, performance evaluation, active risk management and attribution analysis (Hou et al. 2012; Câmara et al. 2009). Therefore, the cost of capital needs to be given attention in relationship to optimal financing of corporate growth.

Furthermore, an important condition for corporations to grow is that they have access to capital for investment in tangible as well as intangible assets. This requires first of all that capital markets are fit for purpose. That actors and institutions in capital markets, such as banks, investment funds and stock markets, have the incentives to properly integrate the internal objective of optimizing cost of capital. An examination in the Nigerian capital market which is supposed to be an avenue for sourcing of long-term funds to finance long-term project is not developed as her foreign counterpart. It has therefore not been able to judiciously perform its primary obligation of meeting long-term capital needs of the deficits sectors through efficient accumulation of capital or mobilization of fund from the surplus units of the economy and effectively channel mobilized funds for economic use (Ojo, 2012) for instance the Nigeria capital market is very illiquid, few listed companies with low volume of equity transaction with low market capitalization which led to the increasing cost of equity capital.

However, the financial sector reforms such as the bank consolidation and recapitalization also aim at making available easy source of debt financing to investors. A critical examination of the function of the institution prove that this objective is yet to be determined in relationship with cost of capital and financing corporate growth. Despite the growing literature, the relationship between cost of capital and optimal financing of corporate growth remain a knowledge gap as existing studies focused on cost of capital and corporate profitability of listed firms. Given the above problems, the controversies surrounding the impact of capital structure on corporate performance and the knowledge gap, this study seek to examine the existing relationship between optimal cost of capital and financing of corporate growth among quoted firms in Nigerian stock exchange.

\section{Literature Review}

\subsection{Cost of Capital}

A firm raises funds from various sources, which are called the components of capital. Different sources of fund or the components of capital have different costs. For example, the cost of raising funds through issuing equity shares is different from that of raising funds through issuing preference shares. The cost of each source is the specific cost of that source, the average of which gives the overall cost for acquiring capital. The firm invests the funds in various assets. So it should earn returns that are higher than the cost of raising the funds. In this sense the minimum return a firm earns must be equal to the cost of raising the fund. So the cost of capital may be viewed from two viewpoints acquisition of funds and application of funds. From the viewpoint of acquisition of funds, it is the borrowing rate that a firm will try to minimize. On the other hand from the viewpoint of application of funds, it is the required rate of return that a firm tries to achieve. The cost of capital is the average rate of return required by the investors who provide long-term funds. In other words, cost of capital refers to the minimum rate of return a firm must earn on its investment so that the market value of company's equity shareholders does not fall.

\subsubsection{Estimating the Cost of Equity Capital}

Estimating the cost of equity involves estimating the expected return on a firm's common stock. The cost of equity includes a risk premium to compensate shareholders for holding a risky equity security rather than a risk-free security:

$C O E_{i}=E\left(r_{i}\right)=r_{f}+r p_{i}$

Where

$\mathrm{COE}_{\mathrm{i}} \quad=$

$\mathrm{E}\left(\mathrm{r}_{\mathrm{i}}\right) \quad=$ and dividends,

$\mathrm{r}_{\mathrm{f}}$ $=\quad$ the risk-free rate, and

firm i's cost of equity, the expected future return on firm i's equity, where returns include capital gains 
There are two general approaches for estimating the cost of equity at a firm level. We use an implied approach which measures the cost of equity as the internal rate of return that equates the present value of forecasted future cash flows to equity holders with the current stock price. In comparison, the realized returns approach uses information in realized ex-post stock returns to generate a cost of equity. In this section we discuss the different implied cost of equity models and explain our choice of the implied approach over the realized returns approach.

\subsection{Implied Approach}

Determining the cost of equity using the implied approach is analogous to determining the nominal yield to maturity on a bond; i.e., finding the discount rate that sets the bond's price equal to the present value of future cash flows. Similarly, the implied cost of equity is the discount rate that sets the current stock price equal to the present value of expected future dividends per share. The relation between the current stock price (P0), the cost of equity (r), and future expected dividends per share $\left(\mathrm{d}_{1}, \mathrm{~d}_{2}, \mathrm{~d}_{3} \ldots\right)$ is represented by the dividend discount model (DDM).

$$
P_{o}=\frac{d_{1}}{(1+r)}+\frac{d_{2}}{(1+r)^{2}}+\frac{d_{3}}{(1+r)^{3}}
$$

In practice, determining a bond's nominal yield to maturity is easier, since future coupon and principal payments are known. Finding the implied cost of equity is much more difficult since future dividends must be forecasted into infinity. The various implied models differ in terms of how this stream of dividends evolves.

\subsection{Gordon Dividend Growth Model}

The simplest form of the DDM, the Gordon Dividend Growth Model, assumes a constant perpetual rate of growth ( $g$ ) in expected dividends per share. With this assumption, dividends are an infinite geometric series, and the cost of equity can be written as a function of the dividend yield plus the constant growth rate:

$$
r=\frac{d_{1}}{P_{o}}+g
$$

Two problems are encountered when estimating the cost of equity using the Gordon Dividend Growth Model. First, it is difficult to estimate a long-term growth rate as typically only shorter-term forecasts are available. In practice, many use the five-year dividend growth rate as a proxy for the long-term rate. Second, in the Gordon Model it is possible to specify that dividends grow at a rate that is greater than economic growth, which implies that dividends will be larger than the economy at some future point. We do not use the Gordon Growth Model in our analysis, but discuss it here to provide a simple intuition as to how growth and dividend assumptions impact the cost of equity.

\subsection{Residual Income Valuation Models}

Residual income valuation (RIV) models address the difficulties in estimating a long term growth rate by utilizing accounting information. These models equate the current share price to the sum of two components: (1) the present value of expected dividends per share over a short or medium-term horizon (N); and (2) a discounted terminal value, which is the present value of the expected share price at the end of the forecast period, assuming that dividends then grow at a constant rate $(\mathrm{gL})$ in perpetuity:

$$
P_{o}=\sum_{t=1}^{N} \frac{d_{t}}{(1+r)^{t}}+\frac{d_{N+1}}{(r-g L)(1+r)^{N}}
$$

RIV models assume clean surplus accounting which requires that earnings are fully allocated between dividends and retained earnings; i.e., whatever portion of earnings that is not paid out in dividends is added to book value of equity. Hence, book value per share $\left(b_{\mathrm{t}}\right)$ evolves according to the following equation:

$$
\begin{aligned}
& b v_{t+1}=b v_{t}+e_{t+1}-d_{t+1} \\
& \begin{array}{ll}
\text { and as roe } & \\
\text { then } b_{\mathrm{t}+1}=b v_{t}\left(1+\operatorname{roe}_{t+1}\left(1-\frac{d_{t-1}}{e_{t+1}}\right)\right. & \mathrm{e}_{\mathrm{t}} / \mathrm{bv}_{\mathrm{t}-1}
\end{array}
\end{aligned}
$$

Assuming that return on book equity and the dividend payout ratio after time $\mathrm{N}+1$ remain constant, the following constraint is imposed on the long-term growth rate of dividends per share (gL) in Equation (4) 
$=g_{L} \operatorname{roe}_{N+1}\left(1-\frac{d_{N-1}}{e_{N+1}}\right)$

Claus and Thomas (2001) implement the RIV model using a four-year forecasting horizon $(\mathrm{N}=4)$ and set the growth rate $\left(\mathrm{g}_{\mathrm{L}}\right)$ equal to the expected inflation rate (pe) in order to calculate a nominal cost of equity. 8 Dividends per share in year five are backed out from Equation (6) as follows:

$$
d_{s}=e_{s}\left(1-\frac{g_{L}}{\text { roe }_{5}}\right)=e s\left(1-\frac{\pi_{e}}{\text { roe }_{5}}\right.
$$

So the cost of equity in the Claus and Thomas model is the value of $r$ that solves the following equation:

$$
P_{o}=\sum_{t=1}^{4} \frac{d_{t}}{(1+r)^{t}}+\frac{d_{5}}{\left(r-\pi_{e}\right)(1+r)^{4}}
$$

If dividends are all positive and the cost of equity is greater than the expected inflation rate, there is only one value of $r$ that will solve this equation.

\subsection{Abnormal Earnings Growth Models}

Another class of implied models assumes that the change in abnormal earnings from year to year grows at a constant rate into perpetuity. This is similar to assuming that the forecasted change in dividends grows at a constant rate, if the change in dividends is calculated as:

$$
d_{2}-d_{1}=\left(e_{2}-e_{1}\right)-g_{L}\left(e_{1}-d_{1}\right)
$$

In the Ohlson and Juettner-Nauroth (2003) version, a closed form solution for the cost of equity can be backed out from the following relation between price, next year's earnings per share estimate and next year's expected dividends per share:

$$
P_{o}=\frac{d_{1}}{r-g_{L}}+\frac{e_{1}\left(g_{s}-g_{L}\right)}{r\left(r-g_{L}\right)}
$$

\section{Where}

$$
\begin{array}{lll}
\mathrm{g}_{\mathrm{s}} & = & \text { short-term dividends per share growth rate } \\
& = & \left(\mathrm{e}_{2}-\mathrm{e}_{1}\right) / \mathrm{e}_{1} \\
\mathrm{~g}_{\mathrm{L}} & = & \mathrm{a} \text { long-term dividends per share growth rate }
\end{array}
$$

Gode and Mohanram (2003) implement this theoretical model of Ohlson and Juetnner-Nauroth by assuming that the short-term growth rate $\left(g_{S}\right)$ is equal to the average of the forecasted growth rate between year one and year two and the average five-year growth rate provided by analysts. Furthermore, they assume that the long-term growth rate $\left(\mathrm{g}_{\mathrm{L}}\right)$ is equal to expected inflation for all firms.

Easton's (2003) model, called the Modified-PEG ratio model,10 is just a special case of the Ohlson and JuettnerNauroth model, where the growth rate in the change in dividends is set equal to zero $\left(\mathrm{g}_{\mathrm{L}}=0\right)$ so that dividends grow by the same dollar amount every year into perpetuity. The current stock price is related to the cost of equity, the next two year's forecasted earnings, as well as the next year's dividend:

$$
P_{o}=\frac{d_{1}}{r}+\frac{e_{1} g_{s}}{r^{2}}
$$

The advantage of the Easton and Ohlson-Juettner-Nauroth models over RIV models is that they yield simple formulas for the cost of equity. RIV models have more terms because they explicitly forecast variables over the short-term before calculating a terminal value. In contrast, the abnormal earnings growth models make assumptions so that the terminal value is calculated immediately, which allows them to be easily inverted to solve for the cost of equity.

\subsection{Hedging and the Cost of Capital}

Corporate finance theory formulates that firm value is the present value of future cash flows. Therefore, the impacts of hedging on firm value can be from: the effect on the cash flow stream and/or the impact on the cost of capital by which future cash flows are discounted. Easley and O'Hara (2004) highlight that the cost of capital is fundamental in corporate policies because of its impact on profitability, and hence investment decisions. Recent studies suggest that hedging has notable influences on the cost of equity. For example, Gay, Lin, and Smith (2010) report that hedging 
affects the cost of equity through a reduction in the covariance of future cash flows. In particular, the cost of equity is reduced when hedging lowers the effective discount factor of future investment payoffs. They document that the cost of equity for hedging firms is 24 to 78 bps lower than those firms that do not hedge.

\subsection{Reduced Bankruptcy Cost}

The probability of bankruptcy or financial distress is considerably higher when a firm's earnings or cash flows are more volatile. Because hedging smoothes corporate income or cash flows, bankruptcy risk is reduced. In particular, Smith and Stulz (1985) suggest that hedging reduces a firm's cash flow volatility and consequently lowers the expected cost of financial distress. As a result, we conjecture that hedging should lead to a lower cost of debt. In addition, highly leveraged firms often cannot afford a large debt capacity since the cost of debt is high. Graham and Rogers (2002) find that hedging helps increase debt capacity, leading to an average increase of $1.1 \%$ in firm value.

\subsection{Lower Agency Cost of Debt}

Myers (1977) suggests that firms with risky debt may forgo positive NPV projects if some or all of the value of the project goes toward the bondholders when poor states occur. Hedging alleviates the underinvestment problem by reducing the probability of the poor states occurring. Therefore, shareholders have greater incentives to invest in value-enhancing projects (Bessembinder (1991). Froot, Scharfstein, and Stein (1993) theorize that hedging curtails the underinvestment problem when a firm faces growth opportunities and a high cost of external financing. In this case, hedging leads to managers following the optimal investment policy by generating sufficient internal funds and having a low cost of capital. Second, hedging mitigates the risk-shifting problem (Campbell and Kracaw, 1990).

\subsection{Lower Level of Information Asymmetry}

Literature indicates that managers have better information about firm performance than outsiders. As the release of information is costly and managers may have incentives to distort or not fully disclose information for private benefits, investors do not have full information on asset values or their information set is noisy. As a result, information asymmetry affects equilibrium asset prices and expected rates of return by influencing the investors' assessments regarding the distribution of future cash flows. Easley and O'Hara (2004) demonstrate that investors demand a higher return on stocks with more private information. Duffie and Lando (2001) argue that information content and quality based on accounting disclosure are critical for bondholders to retrieve a conditional distribution of an issuer's asset value.

\subsection{Empirical Review}

Khaled and Samer (2014) examined the determinants of the rate of return on investment in stocks and the application of it on industrial enterprises, contributed to the ASE, which consists of 91 industrial companies during the study period from 1997- 2009. The study used Multiple Linear Regression Analysis. The Model included a number of independent variables which are the cost of capital, financial leverage, and growth rate of dividends. The results of the study showed that there is appositive effect and statistically significant for growth rate of dividends on rate of return on investment (dependent variable). On the other hand, the study showed no effect with statistical significance for each of the cost of capital and financial leverage on rate of return on investment (dependent variable). It turns out that the effect of the growth rate of dividends on the rate of return on investment is not compatible with the hypotheses of the study, while that the effect of each of cost of capital and Financial leverage on rate of return on investment in the stock, consistent with the hypothesis of the study.

Casmir and Anthony (2012) found that a capital structure of a firm has a negative impact on firm's performance. They proved that highly leverage capital structure caused negative impact on firm's performance but it also provides tax rebate on interest expenses. They used different variables to obtain results such as return on assets, return on equity, debt to equity ratio, assets turnover ratio, firm's size and age, asset tangibility, growth and industrial sector. They used ordinary least square (OLS) model of estimation. They proved that ROA, ROE and asset turnover are important measure of firm's financial performance. They also concluded that tangibility of assets have great impact on firm's performance. They concluded that the firms of their sample size are not utilizing their tangible assets up to their maximum capacity. So, assets tangibility is also a vital measure of firm's performance. They could not prove the result of industry growth.

Ahmad, Abdullah and Roslan (2012) proved that capital structure decision has a vital importance. A wrong decision may cause a negative impact so; great care is required. There are different theories of capital structure such as Modigliani Miller theorem, pecking order theory, static trade off theory and agency cost theory. Pecking order theory focuses on the use of an organization's internal funds. They used return on assets, return on equity with short term and long term debt and total debt, size, asset growth, firm growth and efficiency. They used series of regression analysis to measure the desired results. They studied pecking order theory, Modigliani Miller theorem and static trade off theory to understand the relationship between capital structure and firm's performance. The study found that short and long term debts with ROA and ROE and total debt of capital structure has great impact on firm's performance. 
Chowdhury and Paul (2010) found that a company injects capital to generate revenue. If capital of a company is $100 \%$ equity than all the earnings after tax goes to shareholders if capital structure consists debt than a part of profit is also given to creditors as a rent of their funds' use. According to financial experts use of debt up to specific point is profitable otherwise it is harmful. They used different variables as; share price, firm size, profitability, public European Journal of Business and Management ownership in capital structure, dividend payout, asset and operating efficiency, growth rate, liquidity and business risk. They used cross sectional times series regression model to measure the relationship of all these variables. On the basis of their analysis they concluded that if capital structure of a firm is designed in a good manner it multiplies the value of firm. They also proved that if a firm makes amendments in its capital structures it also causes a positive impact on its value.

Umar, Tanveer, Aslam and Sajid (2012) proved that capital structure has a vivid impact on firm's financial performance. It is a way through which a firm is financed. They used different variables of financial measure such as return on asset, return on equity, earning per share, price earnings ratio, earnings before interest and tax and net profit margin.

P-Eriotis, Frangouli and Ventoura (2011) noted that firms financed with equity are more profitable as compare to those financed by debt. If debt amount is high than a part of its profits is given as interest which ultimately reduces its profits. So, capital structure choice has vital importance. Debt to equity ratio is used in order to examine its impact on firm's profitability. Fix effect model and random effect model are used. It is analyzed that debt negatively impacts a firm's profitability because mostly the cost of debt is high than profits of the firm. They also concluded that firms liked to compete with one and another rather than cooperating.

Imran (2012) investigated a relationship between a firm's performances, equity ownership and capital structure. Many organizations use debt as a controlling measure. The external parties keep check and balance on management's decision making and generate better results. Debt to equity ratio to measure leverage (capital structure). Regression model is used to calculate desired outcomes. The results of this study showed that organizations with high leveraged showed more profit of those firm which use their extra cash and reduce it from management. Family ownership has a positive relationship with performance.

Adeyemi and Oboh (2011) studied a sample size of 66 companies quoted in the Nigerian stock exchange and found that a significant relationship between capital structure and the performance of quoted firms in Nigeria using primary data from questionnaire. Nosa and Ose (2010) used growth opportunity, non debt task shield, tangibility, profitability and earning volatility also found positive and significant relationship with the dependent variable which is corporate performance.

Nicholas et al, (2013) examined Accounting Information and Cost of Capital: A Theoretical Approach. The primary goal of the study is to provide a theoretical model that shows explicit solutions for equilibrium prices and derives the equilibrium required return for the firm's stock price. In other words, this theoretical study provides a direct link between accounting information, related to the firm's reports, and the cost of capital within an equilibrium setting. Accounting information is judged to be of high value because it affects the market's ability to direct firms' capital allocation choices. The findings showed that an increase in expected cash flows, coming from improvements in the quality of accounting information, leads to a reduction in the firm's cost of capital.

\section{Research Methods}

This study used secondary data which was handpicked from the annual report and statement of account of selected quoted firms on the Nigerian Stock Exchange for the period.

\subsection{Model Specification}

Summary statistics for the variables was calculated. The analysis utilized time series data with generalized least squares regression. The most basic test involved regressing the dependent variable, equity financing, debt financing and corporate growth proxy by profitability of the quoted firms against the four independent variables which are cost of equity, cost of debt, cost of preference share and weighted average cost of capital. Thus, in line with the objectives of the study, the following models are formulated:

\section{Model I}

$\mathrm{EQF}=\mathrm{f}(\mathrm{CDC}, \mathrm{CEQC}, \mathrm{WACC})$

$\mathrm{EQF}=\alpha_{0}+\beta_{1} \mathrm{CDC}+\beta_{2} \mathrm{CEQC}+\beta_{3} \mathrm{WACC}+\varepsilon \mathrm{i}$

Model II

$\mathrm{DF} \quad=\mathrm{f}(\mathrm{CDC}, \mathrm{CEQC}, \mathrm{WACC})$

$\mathrm{DF}=\alpha_{0}+\beta_{1} \mathrm{CDC}+\beta_{2} \mathrm{CEQC}+\beta_{3} \mathrm{WACC}+\varepsilon \mathrm{I}$

Model III

ROI $=\mathrm{f}(\mathrm{CDC}, \mathrm{CEQC}, \mathrm{WACC})$ 


$$
\mathrm{ROI}=\alpha_{0}+\beta_{1} \mathrm{CDC}+\beta_{2} \mathrm{CEQC}+\beta_{3} \mathrm{WACC}+\varepsilon \mathrm{i}
$$

Model IV

$\begin{array}{ll} & \mathrm{FM} \\ \mathrm{FM} & \mathrm{f}(\mathrm{CDC}, \mathrm{CEQC}, \mathrm{WACC}) \\ & =\alpha_{0}+\beta_{1} \mathrm{CDC}+\beta_{2} \mathrm{CEQC}+\beta_{3} \mathrm{WACC}+\varepsilon \mathrm{i}\end{array}$

Where:

$\mathrm{EQF} \quad=\quad$ Equity Financing

DF $\quad=\quad$ Debt Financing

ROI $=$ Return on Investment

FM = Financing Mix proxy by Debt Equity Ratio

CDC $\quad=\quad$ Cost of Debt Capital

CEQC $\quad=\quad$ Cost of Equity Capital

WACC $=\quad$ Weighted Average Cost of Capital

$\alpha=$ Regression Constant

$\beta_{1-} \beta_{3} \quad=\quad$ Regression Coefficient

ci $\quad=\quad$ Error Term

\section{Techniques of Analysis}

The models stated will be analyzed using the multiple regression models. The Statistical Package for Social Science (SPSS) will be used to examine the relationship between the dependent and the independent variables as formulated in the models. The idea behind regression analysis is the statistical dependence of one variable, the dependent variable, on one or more variables, the independent or explanatory variables. The objectives of such analysis are to estimate or predict the mean or average value of the dependent variable on the basis of the known or fixed values of the explanatory variables (Gujarati and Porter, 2009).

5. Presentation and Analyses of Results

Table 1: Tolerance and Variance Inflation Factor (VIF)

\begin{tabular}{lll}
\hline MODEL I & TOLERANCE & VIF \\
\hline CDC & .229 & 4.369 \\
\hline CEC & .294 & 3.399 \\
\hline$W A C C$ & .280 & 3.574 \\
\hline
\end{tabular}

Source: SPSS print out 22.0 (2019)

The variance inflation factor result shows that all the variables fall below 4.0 and 10.0 which is the minimum and the maximum variance inflation coefficient. From the above, the study conductively conclude that the variance inflation factor.

Table 2: Colinearity Diagnostic and Durbin Watson Test

\begin{tabular}{|c|c|c|c|c|c|c|}
\hline \multirow[t]{2}{*}{ Model } & \multirow[t]{2}{*}{ Eigen value } & \multirow[t]{2}{*}{ Cond index } & \multirow[t]{2}{*}{ Constant } & \multicolumn{3}{|c|}{ Variables Proportion } \\
\hline & & & & $\mathrm{CDC}$ & CEQ & WACC \\
\hline 1 & 6.321 & 1.000 & .00 & .00 & .00 & .00 \\
\hline 2 & .418 & 3.890 & .51 & .11 & .04 & .00 \\
\hline 3 & .174 & 6.030 & .01 & .40 & .95 & .06 \\
\hline 4 & .057 & 10.497 & .49 & .49 & .00 & .00 \\
\hline
\end{tabular}

Source: SPSS print out 22.0 (2019)

The Eigen value provides an indication of how many distinct dimensions they are among the independent variables, when several Eigen value are close to 0, the variables are highly intercorrelated and the market is said to be unconditioned; which means small changes in data values will lead changes in the estimates of the coefficients. From the table above, the Eigen values are greater than 0, this proves that the variables are not highly correlated, this means the absence of multicolinearity. A condition index greater than 15 indicates a possible problem and an index greater than 30 suggests a serious problem. From the table above, the condition index are less than 15 and 30 that 
means the absence of serial autocorrelation among the variables. The Durbin Watson statistics for the models are greater than 1.00 but less than 2.00 which means the presence of positive autocorrelation among the variables.

Table 3: Effect of Cost of Capital on Equity Financing

\begin{tabular}{llll}
\hline VARIABLES & CDC & CEC & WACC \\
\hline Unstandarized $\beta$ & -5.302 & -17.776 & 762.808 \\
\hline Standarized $\beta$ & -.208 & .534 & .758 \\
\hline Standard Error & 13.836 & 15.927 & 493.540 \\
\hline Partial Correlation & -.110 & .307 & .407 \\
\hline Zero Order & -.016 & -.115 & -.169 \\
\hline T-Statistics & -.383 & -1.116 & 1.546 \\
\hline T-Significant & .708 & .286 & .146 \\
\hline $\mathrm{R}^{2}$ & .439 & $\mathrm{R}^{2}$ & .193 \\
\hline F-ratio & .956 & F-sig & .445 \\
\hline
\end{tabular}

Source: Extracts from SPSS Window (22.0)

\section{Interpretation of Regression Results}

The regression result presented in the above table shows that cost of debt capital and cost of equity capital have negative relationship on equity financing, this means that the negative coefficient of 5.302CDC and 17.776CEC would reduce equity financing by $5.3 \%$ and $17.7 \%$ for a unit increase in the independent variables while the positive coefficient of 762.808WACC will add to equity financing for a unit increase in weight average cost of capital. The models show that the independent variables can explain $19.3 \%$ variation on the dependent variable. The T-statistics and the T-significant shows that the models are statistically not significant. The correlation coefficient shows that the relationship between the dependent and the independent variable is proxy by $43.9 \%$. The correlation coefficient of the independent variables confirms the relationship as reveal by the unstandardized and standardize $\beta$ coefficient. The F-ratio found that the regression model is statistically not significant.

Table 5: Effect of Cost of Capital on Debt Financing

\begin{tabular}{llll}
\hline VARIABLES & CDC & CEC & WACC \\
\hline Unstandarized $\beta$ & 1.865 & -.843 & 17.463 \\
\hline Standarized $\beta$ & .878 & -.304 & .208 \\
\hline Standard Error & .733 & .844 & 26.157 \\
\hline Partial Correlation & .592 & -.277 & .189 \\
\hline Zero Order & .801 & .581 & .703 \\
\hline T-Statistics & 2.543 & -.999 & .668 \\
\hline T-Significant & .026 & .338 & .517 \\
\hline $\mathrm{R}^{2}$ & .820 & $\mathrm{R}^{2}$ & .673 \\
\hline F-ratio & 8.227 & F-sig & .003 \\
\hline Constant $\alpha_{0}$ & 708.880 & ST-Statistics & 2.022 \\
\hline Sig. & .668 & & \\
\hline
\end{tabular}

Source: Extracts from SPSS Window (22.0)

\section{Interpretation of Regression Results}

The regression result presented in the above table shows that cost of debt and weighted average cost of capital have positive effect on debt financing, this means that the negative coefficient of 1865CDC and 17.463WACC proved that an increase of $10 \%$ will lead to $18.6 \%$ increase and $17.4 \%$ in debt financing while the negative coefficient of $.843 \mathrm{CEC}$ will reduce debt financing by $8.4 \%$ for a unit increase in the variables cost of capital. The models show that the independent variables can explain $67.3 \%$ variation on the dependent variable. The T-statistics and the Tsignificant shows that CDC is statistically significant while CEC and WACC are statistically not significant. The correlation coefficient shows that the relationship between the dependent and the independent variable is proxy by $82 \%$ correlation coefficient of the independent variables confirms the relationship as reveal by the unstandardized and standardize $\beta$ coefficient. The F-ratio found that the regression model is statistically significant. 
Table 6: Effect of Cost of Capital on Return on Investment

\begin{tabular}{llll}
\hline VARIABLE & CDC & CEC & WACC \\
\hline Unstandarized $\beta$ & .104 & -.299 & 120.197 \\
\hline Standarized $\beta$ & .008 & -.018 & .244 \\
\hline Standard Error & 7.312 & 8.417 & 260.838 \\
\hline Partial Correlation & .004 & -.010 & .132 \\
\hline Zero Order Correlation & .197 & .179 & .237 \\
\hline T-Statistics & .014 & -.036 & .461 \\
\hline T-Significant & .989 & .972 & .653 \\
\hline $\mathrm{R}^{2}$ & .237 & $\mathrm{R}^{2}$ & .056 \\
\hline F-ratio & .868 & F-sig & .868 \\
\hline Constant $\alpha_{0}$ & -1958.976 & T-Statistics & -.560 \\
\hline Significant & .586 & & \\
\hline
\end{tabular}

Source: Extracts from SPSS Window (22.0)

\section{Interpretation of Regression Results}

The regression result presented in the above table shows that cost of debt and weighted average cost of capital have positive effect on debt financing, this means that the positive coefficient of .104CDC and 120.197WACC proved that an increase of $10 \%$ will lead to $0.4 \%$ increase and $120 \%$ in return on investment and weighted average cost of capital while the negative coefficient of .229CEC will reduce return on investment by $2 \%$ for a unit increase in the variables cost of capital. The models show that the independent variables can explain 5\% variation on the dependent variable. The $\mathrm{T}$-statistics and the $\mathrm{T}$-significant shows that all the independent variables are statistically not significant. The correlation coefficient shows that the relationship between the dependent and the independent variable is proxy by $23.7 \%$ correlation coefficient of the independent variables confirms the relationship as reveal by the unstandardized and standardize $\beta$ coefficient. The F-ratio found that the regression model is statistically not significant.

Table 7: Colinearity Diagnostic and Durbin Watson Test

\begin{tabular}{|c|c|c|c|c|c|c|}
\hline \multirow[t]{2}{*}{ Model } & \multirow{2}{*}{$\begin{array}{l}\text { Eigen } \\
\text { value }\end{array}$} & \multirow{2}{*}{$\begin{array}{l}\text { Cond } \\
\text { index }\end{array}$} & \multirow[t]{2}{*}{ Constant } & \multicolumn{3}{|c|}{ Variables Proportion } \\
\hline & & & & $\overline{C D C}$ & CEQ & $\overline{\text { WACC }}$ \\
\hline 1 & 3.998 & 1.000 & .00 & .00 & .00 & .00 \\
\hline 2 & .002 & 48.747 & .51 & .11 & .04 & .00 \\
\hline 3 & .000 & 90.351 & .00 & .40 & .95 & .06 \\
\hline 4 & .000 & 117.075 & .49 & .49 & .00 & .94 \\
\hline
\end{tabular}

Source: SPSS print out 22.0 (2019)

The Eigen value provides an indication of how many distinct dimensions they are among the independent variables, when several Eigen value are close to 0 , the variables are highly intercorrelated and the market is said to be unconditioned; which means small changes in data values will lead changes in the estimates of the coefficients. From the table above, the Eigen values are greater than 0, this proves that the variables are not highly correlated, this means the absence of multicolinearity. A condition index greater than 15 indicates a possible problem and an index greater than 30 suggests a serious problem. From the table above, the condition index are less than 15 and 30 that means the absence of serial autocorrelation among the variables except weighted average cost of capital with the condition index of 117.075. The Durbin Watson statistics for the models are greater than 1.00 but less than 2.00 which means the presence of positive autocorrelation among the variables.

Table 8: Effect of Cost of Capital on Financing Mix

\begin{tabular}{llll}
\hline VARIABLES & CDC & CEC & WACC \\
\hline Unstandarized $\beta$ & 1.201 & 3.832 & 46.058 \\
\hline Standarized $\beta$ & .230 & .563 & 224 \\
\hline Standard Error & .911 & 1.049 & 32.497 \\
\hline Partial Correlation & .356 & .726 & .379 \\
\hline \hline CC) (7) (8) & &
\end{tabular}




\begin{tabular}{llll}
\hline Zero Order & .880 & .927 & .854 \\
\hline T-Statistics & 1.318 & 3.654 & 1.417 \\
\hline T-Significant & .212 & .003 & .182 \\
\hline $\mathrm{R}^{2}$ & .196 & Adj. $\mathrm{R}^{2}$ & .895 \\
\hline F-ratio & 43.705 & F-sig & .000 \\
\hline Constant $\alpha_{0}$ & -1420.280 & T-Statistics & -3.261 \\
\hline Significant & .007 & & \\
\hline \multicolumn{4}{c}{ Source: Extracts from SPSS Window (22.0) }
\end{tabular}

\section{Interpretation of Regression Results}

Analyses in the regression results presented in the above table indicates that cost of capital such as cost of debt, cost of equity and weighted average cost of capital of the selected firms have positive relationship with the financing mix of the firms. The positive coefficient of 1.201 as the regression parameter for cost of debt, 3.832 for cost of equity and 46.058 for weighted average cost of capital reveal that a unit increase on the independent variable will lead to significant increase such as $12.0 \%, 38.3 \%$ and $460.5 \%$ increase on the dependent variable. The $\mathrm{R}^{2}$ and the adjusted $\mathrm{R}^{2}$ reveal that $91.6 \%$ and $89.5 \%$ variation on the dependent variable can be traced to variation on cost of capital. The F-statistics and F-significant justifies that the model is adequate in predicting variation on the dependent variable. The findings of the model proved that increase in cost of capital increase the financial mix of the quoted firms. This is contrary to the expectation of the results but justifies the opinion of Miller and Modigliani as against the Gordon. The positive relationship between the variables could be traceable to the inability of the firms to source alternate source of capital for investment but force to borrow or float equity without considering the cost.

\section{Discussion of Findings}

The relationship between corporate capital structure and the performance of quoted firms has long been a point of controversy among scholars in corporate finance. Unlike the dividend policy that determines the rate at which the management determines the proportion of its capital that will be distributed to shareholders and the proportion to be retain, capital structure determine the proportion of the company's capital that is internally generated known as equity capital and the proportion that is borrowed outside the firm known as debt capital. Optimal combination of the two components of capital determines the cost of capital and the financial structure of the corporate organization. Higher cost of debt capital will results in formulating policies that will enhance internally generate capital such as higher retention ratio and lower dividend payout ratio or increasing the equity share capital through floatation of equities by rights issues or by public offer (Pandey, 2005). This illustrates the trade-off theory as formulated by Meyer.

Regression results from model I of this study found that cost of capital have no significant effect on equity financing of the selected manufacturing firms in the study as the explained variation reveals that the independent variables which are cost of debt, cost of equity and weighted average cost of capital can only explain $19.3 \%$ explained variation on the dependent variable. The $\beta$ coefficient of the variables proved that cost of debt and cost of equity capital have negative relationship with equity financing while weighted average cost of capital have positive relationship. The negative effect of the variables confirms the apiriori expectation of the results as increase in cost of capital discourages investment according to economic theory. This means that increase in cost of capital will discourage investment of the selected manufacturing firms. The findings confirm the findings of Lotfi (2004) on the negative effect of cost of capital on fixed assets of selected firms on the floor of Kenya stock exchange. It also validates the findings of Hussain et al., (2012) on the effect of cost of capital on corporate profitability of selected manufacturing firms in India. The positive effect of weighted average cost of capital can be traced to management factors and policies formulated to leverage the cost of capital and decreasing dividend payout ratio and increasing retention ratio.

Model II was formulated to examine the relationship between cost of capital and debt financing. The regression result found that cost of debt and weighted average cost of capital have positive but insignificant relationship with debt financing. It reveals that an increase in cost of debt and weighted average cost of capital will enhance cost of debt financing. This finding is contrary to the expectation of the study as the variables are expected to have a negative effect on the dependent variable. The positive effect can be traced to opinion of Oseigbu (2005) that found positive relationship between interest rate and bank lending and was blamed on the ineffectiveness of the financial sector and the inability of the corporate firms to formulate polices that will leverage the challenging effect of cost of capital within the business environment. However, cost of debt has positive and significant effect on debt financing. This finding confirms the findings of Akani and Lucky (2016) on the positive effect of capital structure and shareholders' value of quoted commercial banks in Nigeria. 
Model III was formulated to investigate the effect of cost of capital on the profitability of selected manufacturing companies and the regression results found that cost of debt and weighted average cost of capital have positive but insignificant effect while cost of equity have negative but insignificant effect. The results reveal that the independent variable can only explain 5\% variation on the dependent variable; this shows that cost of capital is statistically not significant on the profitability of the selected manufacturing firms. Theoretically, increase in cost of capital discourage investment and therefore the negative effect of the variable on profitability confirm the a-priori expectation of the results while the positive effect can be traced to the fact that corporate firms has no valid option on source of capital and are forced to obtain fund whether the cost is high or not.

\section{Conclusion and Recommendation}

\subsection{Conclusion}

This study investigated the relationship between cost of capital and financing of corporate growth of 50 selected manufacturing firms listed on the floor of Nigerian stock exchange using time series data from $2000-2015$. Financing of corporate growth was proxy as equity capital to total capital, debt capital to total capital and return on investment while cost of capital was proxy by the traditional method as formulated by Pandey (2005) as cost of debt, cost of equity and weighted average cost of capital. From the findings of the study, we draw the following conclusion:

- That the relationship between cost of capital and equity financing is statistically not significant. Cost of debt and cost of equity have negative and insignificant effect while weighted average cost of capital has positive but insignificant effect on the dependent variable. The model summary shows that the independent variables could only attest $19.3 \%$ variation while the F-statistics shows that the model is statistically not significant.

- That cost of capital has significant relationship on debt financing as the model summary portray that the independent variables have a correlation coefficient of $82 \%$, an $\mathrm{R}^{2}$ of $67.3 \%$ and the model is statistically significant. Cost of equity capital has negative effect while cost of debt and weighted average cost of capital have negative effect.

- That cost of capital has no significant effect on return on investment of the selected manufacturing companies as the multiple $\mathrm{R}$ shows $23.7 \%, \mathrm{R}^{2}$ of $5.6 \%$ and the model tested not significant despite the positive effect of cost of debt and weighted average cost of capital.

\subsection{Recommendation}

- Management should formulate internal policy that will enhance the realization of optimal capital structure of the firm which determines the combination of equity capital and debt capital as the capital structure of the firm and the business environment should be well diagnosed and tactical measures used to ensure that cost of capital does not affect the investment decision of the firms and the profitability.

- Formulating capital structure of the firm should be well examined with the investment policy of the firms to avoid high cost of capital that will not enhance investment financing of the firms and the environmental factors should be acknowledged in formulating cost of capital to avoid risk associated with inadequate or wrong capital structure of the firm to enhance profitability.

- External source of capital such as debt should be properly appraised and integrated with the investment policy of the firms to leverage the high cost of debt and its effect on investment and profitability and cost of equity should be integrated with the objective of maximizing shareholders' wealth through investment policies.

- The regulatory authorities should formulate policies of minimizing the cost of capital on the investment decision of the listed firms and the macroeconomic and the monetary policy should be considered and

\section{References} appraised in determining the capital structure of the firms.

Abor, J., (2005). The effect of capital structure on profitability: empirical analysis of listed firms in Ghana. International Research Journal of Finance and Economics, 15(2),56-59.

Adeyemi, S. B., \& Oboh, C. S. (2011). Perceived Relationship between Corporate Capital Structure and Firm Value in Nigeria. International Journal of Business and Social Science, 2(19), 131-143.

Ahmad, Z., Abdullah, N. M. H., \& Roslan, S. (2012). Capital structure effect on firms performance; focusing on consumers and industrial sectors on Malaysian firms. International Review of Business Research Papers, $8(5), 137-155$.

Bessembinder, H. (1991). Forward contracts and firm value: Investment incentive and contracting effects. Journal of Financial \& Quantitative Analysis 26, 4 (12), 519-532.

Camara, B, (2009). Changes in Capital and Risk: An Empirical Study of European Banks, Working Paper. 
Campbell, T. S., \& Kracaw,W.A (1990). Corporate risk management and incentive effects of debt. Journal of Finance, 45 (1), 1673-1686.

Chowdhury S. P. and Paul (2010). Impact of Capital Structure on Firm's Value: Evidence from Bangladesh. Business and Economic Horizons,3(3),111-122.

Claus, J. \& Thomas, J. (2001). Equity risk premium as low as three percent? Evidence from analysts' earnings forecasts for domestic and international stocks. Journal of Finance, 56 (5), 1629-1666.

Duffie D, D, Lando (2001): Tenn Strueture of Credit Spreads with Incomplete Accounting Information. Econometrica. (69) 633-664.

Easley D. and O'Hara M.(2004). Information and the Cost of Capital," Journal of Finance, 59,(4)1553-1584.

Easton, P. D. (2003). PE ratios, PEG ratios, and estimating the implied expected rate of return on equity capital. The Accounting Review 79 (1)73-95

Fama, E. F., \& French, K. R., (2004). Testing tradeoff and pecking order predictions about dividends and debt, Review of financial studies, 15 (1), 1-33.

Froot, K. A., D. S. Scharfstein \& J.C. Stein, (1993). Risk management: coordinating corporate investments and financing policies, Journal of Finance 5(2), 1629-1658

Gay, G. D., Lin, C. M., \& Smith, S. D., (2010). Corporate derivatives use and the cost of equity, Journal of Banking and Finance, 35, 1491-1506

Gode, D., \& Mohanram, P. (2003). Inferring the cost of capital using the Ohlson-Juettner model. Review of Accounting Studies, 8(4), 399-431. http://dx.doi.org/10.1023/A:1027378728141

Graham, J.R. and Rogers (2002). Do personal taxes affect corporate financing decisions? Journal of Public Economics, Elsevier, 73: 41-73

Gujarati, D. N., and Porter, D. C., (2009), Basic Econometrics International Edition, Singapore: McGraw-Hill.

Khaled, A. M., \& Samer, F. O., (2014). Impact of cost of capital, financial leverage, and the Growth Rate of Dividends on Rate of return on investment: An Empirical study of Amman stock Exchange.

Maina, L., \& Kondongo, O. (2013). Capital structure and financial performance in Kenya: evidence from firms listed at the Nairobi Securities Exchange. Paper Presented at the Jomo Kenyatta University of Science \& Technology Research Conference. Kenya

Myers, S.C.(1977) The capital structure puzzle. The Journal of Finance. 39(3), 575-592

Nicholas, A, (2013). Accounting Information and Cost of Capital. A Theoretical Approach: Modern Economy, 6 (8), $589-596$.

Ohlson, J., \& Juettner-Nauroth, B. (2003). Expected EPS and EPS Growth as Determinants of Value, Working Paper, New York University.

Ongore, V.O. (2011). The relationship between ownership structure and firm performance: An empirical analysis of listed companies in Kenya. African Journal of Business Management, 5, (6), 2120-8.

Penrose, E. T. (1959). The Theory of the growth of the firm. New York: John Wiley models of consumption and leisure choice under uncertainty. The Quarterly Journal of Economics, 103(1), 51-78.

P-Eroitis, F., \& Ventoura, H. (2011). Profit Margin and Capital Structure. The Journal of Applied Research. 24(5), 111-119.

Smith, C.W., \& Stulz (1985). The determinants of firms' hedging policies. Journal of Financial and Quantitative Analysis, 20( 4), 391-405

Tushaj, A., (2010). Market Concentration in the Banking Industry": Evidence from Albania, Working Paper, 73 (9), $1-32$.

Umar, M., Tanveer, Z., Aslam, S., \& Sajid, M. (2012). Impact of capital structure on Firm's financial. Research Journal of Finance and Accounting, 3(9), 1-12.

Young, S. D, \& Saadi, S. (2011). Using the capital asset pricing model and arbitrage pricing theory in capital budgeting. In: Baker HK, English P (eds) Capital budgeting valuation. Financial analysis for today's investment projects. Wiley, Hoboken, NJ, 363-380

\section{Copyrights}

Copyright for this article is retained by the author(s), with first publication rights granted to the journal. This is an open-access article distributed under the terms and conditions of the Creative Commons Attribution license (http://creativecommons.org/licenses/by/4.0/). 